\title{
Be polite
}

\author{
Samina Ali ${ }^{1,2}(\mathbb{D}$
}

Received: 3 September 2021 / Accepted: 21 September 2021 / Published online: 5 October 2021

(C) The Author(s), under exclusive licence to Canadian Association of Emergency Physicians (CAEP)/ Association Canadienne de Médecine d'Urgence (ACMU) 2021

Keywords Racism · Anti-racism · Wellness

It started like any other emergency department day shift. I was seeing the trickle of early morning children, spending as much time treating illness as acknowledging pandemicrelated stress. A 17-year-old was brought in by the police, belligerent and uncooperative. I arrived in the room with my trainees, who I asked to stay back and observe, as i wanted to protect them from potential physical harm and also rapidly de-escalate the situation.

As I entered the room, there were multiple police officers, security guards, nurses, and a social worker, all wearing full personal protective equipment. All, with the exception of myself, were white. The social worker was already speaking to this young woman and introduced me, explaining "Dr. Ali is here to help". As I spoke to her, the only part of my body that was visible were my eyes behind my glasses. I was covered by a yellow gown, blue gloves, face mask, and hospital-issue scrubs. I looked like every other healthcare provider in that room. Or so I thought.

This young woman was not willing to engage with me. At first, I thought it was because she was upset, maybe intoxicated or confused. She kept repeating 'Oh no, not her'. And while, deep down, I instinctively knew what 'not her' REALLY meant, I held on to the possibility that I was misinterpreting her intent... maybe she just didn't want a doctor to examine her, perhaps she wanted to go home or hated needles... all plausible reasons to yell 'not her'.

Alas, she did not hate needles. She only hated me. "No offense," she said, "but not her... I'm not racist or

Samina Ali

sali@ualberta.ca

1 Departments of Pediatrics \& Emergency Medicine, Faculty of Medicine \& Dentistry, University of Alberta, 3-583, ECHA, 11405-87 Avenue, Edmonton, AB T6G 1C9, Canada

2 Women and Children's Health Research Institute, University of Alberta, Edmonton, AB, Canada anything... but not her..." She kept saying this, again and again, each time driving a knife deeper into my heart. Sweet girl, I wanted to say, I've got your back; let me help you for a few hours. But she wouldn't even acknowledge my presence. Instead, she spoke to the social worker, who was a valid and worthy human, and who deserved to be spoken to politely, albeit somewhat loudly. Unlike me. I was unworthy of eye contact or acknowledgement. I was, by definition, invalidated.

The well-meaning social worker asked this young woman to 'be polite' and told her "Dr. Ali is a very kind doctor". I asked my patient to help me understand what the problem was; I was here to help her, and I really wanted to get her out of the cuffs and make sure that she was okay. She continued to make similar statements and then told us how 'my people' had stolen 'her people's jobs'. On and on she continued, erasing any doubts that she might not be racist.

I recognized that establishing a therapeutic alliance was not going to be possible. She was medically stable and was attended to by multiple nurses who had been quietly listening to this exchange, thus far. So, with my heart pounding out of my chest, I told her "Okay, I see that you will not be able to work with me to treat you, so I will leave now. You will have to stay here with the police officers until we find another doctor". I walked out of the room, face burning with inexplicable shame, and asked a colleague to care for this patient.

I then led my own critical incident debriefing because no one else would acknowledge what just happened. I needed my trainees to know that this was not okay. Leading this debriefing hurt deeply. My medical student cried. My resident was furious, pounding his fist on the desk in frustration. In part, I think their sadness and anger was because they did not know what to do to support me, nor did they see anyone else modeling it. They were hurt and disheartened, seeing not even a vaguely acceptable response to this incident from their role models. 
The social worker later apologized to me for the young woman's rudeness. I corrected her that it was not rudeness, but racism. Rudeness is when a grumpy teen rolls their eyes at me. This. Was. Racism. It is deeply personal and borne of the trauma of witnessing my soft-spoken parents looking painfully bewildered as strangers would regularly feel empowered to hurl racist comments at them in front of their children. Similarly, her behaviour likely stemmed from watching her parents hurl those very same insults. This behaviour and its consequences had far-reaching and strangulating roots for all of us. This was so much more than rudeness.

When I reflect back on this incident what strikes me is how I felt. I understood why I felt angry and hurt. But the dominant feelings were humiliation and confusion as to why I felt lesser. My colleague, literally and figuratively my great white saviour, had to dig me out of this hole I was in. I was embarrassed that I had to ask for help, as if I was at fault and deserved this treatment. Asking a white person to bail me out of a problem that was due to the colour of my skin was mortifying. I have seen this colleague on numerous occasions, since; I still feel dis-ease in her presence. Like she knows my dirty little secret.

I am not an expert in anti-racism. But I know enough to know that my colleagues' actions (or lack thereof) in the moment weren't enough. I am an intelligent, accomplished physician. I am a good person. But in that moment, I was nothing, both in that young woman's eyes and my own. A lifetime of being 'othered' in subtle and not-so-subtle ways led me to wholly internalize that this child had priority and authority over me, and that I would get into trouble for not meeting her needs. This little girl in handcuffs and a ripped t-shirt used her words to strip me of my dignity and worth, in front of ten other fellow human beings. And no one did anything. Not because they are bad people. But because they didn't know what to do. So, I ask, what do we do as an emergency community, to strengthen our response beyond the quintessentially Canadian advice to 'be polite'?

Funding None.

\section{Declarations}

Conflict of interest The author has no conflicts of interest relevant to this article to disclose. 